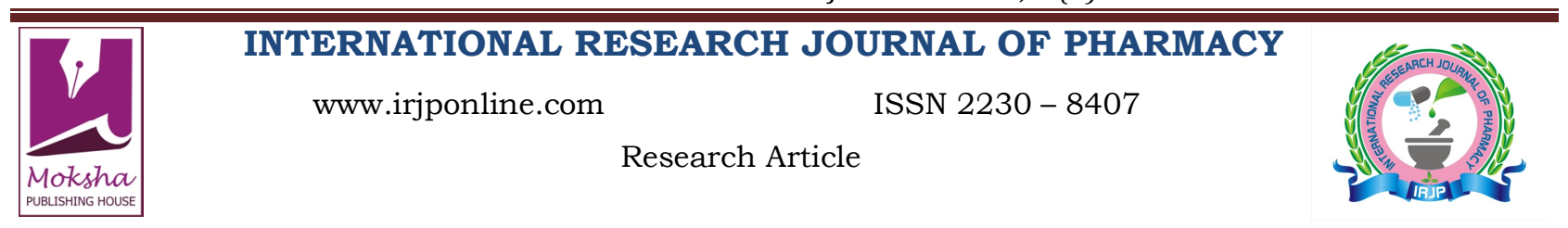

\title{
SEQUESTRATION PROPERTY OF SPIRULINA AGAINST LEAD INDUCED HISTOLOGICAL CHANGES IN MALE ALBINO WISTER RAT RATTUS NORVEGICUS \\ K.Hemalatha ${ }^{1}$, K.Pugazhendy ${ }^{1}$, M.Meenambal ${ }^{1}$, C.Jayanthi ${ }^{2}$ \\ ${ }^{1}$ Department of Zoology, Annamalai University, Annamalai nagar, Tamilnadu, India \\ ${ }^{2}$ Department of Education, Annamalai University, Annamalai nagar, Tamilnadu, India \\ Email: pugalendy@rediffmail.com
}

Article Received on: 14/01/13 Revised on: 02/02/13 Approved for publication: 11/03/13

DOI: $10.7897 / 2230-8407.04330$

IRJP is an official publication of Moksha Publishing House. Website: www.mokshaph.com

(C) All rights reserved.

\section{ABSTRACT}

Lead acetate induces the histological changes in liver and kidney tissues of the male albino Wister rat were observed by light microscopy. The rats were exposed to sublethal concentration of lead acetate $1.896 \mathrm{mg} / \mathrm{kg}$ body wt for seven days with parallel untreated control, lead acetate along with spirulina $2 \mathrm{mg} /$ Kgbody wt and spirulina $2 \mathrm{mg} / \mathrm{Kg}$ body wt groups were maintained. Liver and kidney tissue used for histological studies. No pathological changes were observed in the untreated control and spirulina alone groups. Lead acetate treated group shows sevier histological changes were noticed and lead acetate along spirulina treated group cell recover was observed.

Keywords: lead acetate, Spirulina, histology, albino rat.

\section{INTRODUCTION}

Heavy metals are extremely toxic and ubiquitous in natural environments and they occur in soil, surface water and plants, which readily mobilized by human activities such as mining and dumping of industrial waste in natural habitats such as forests, rivers, lakes and ocean ${ }^{1}$. Metals are nonbiodegradable and also considered as major environmental pollutants causing cytotoxic mutagenic and carcinogenic effects in animals ${ }^{2}$. Among the heavy metals lead $(\mathrm{Pb})$ are found at relatively high levels in crops, vegetables and pasturage herbs for animals ${ }^{3}$. These metals are transported and concentrated through the food chain and can accumulated in the human body and cause chronic poisoning, leading to cancers and other diseases ${ }^{3}$. Lead toxicity is probably the most common form of heavy metal intoxication. It is well documented that, one of the most dangerous and insidious poisons. It continuous environmental and occupational exposure may contribute to renal, nervous, hepatic, hematological and reproductive disorders in man and animals ${ }^{4}$. Liver and kidney being one of the major organs involved in the storage, biotransformation and detoxification of toxic substances. The observed toxicity induced by lead acetate in rats was similar to those previously reported by ${ }^{5,6,7}$. Histological changes provide a method to detect effects of irritants, especially chronic, in various tissues and organs ${ }^{8}$. Spirulina, a blue green algae known for its rich energy value, is used as a protein supplement approximately by 100 million people worldwide, especially in countries like Japan, USA, Thailand Taiwan, India, etc Spirulina has been labeled as a powerful food, rich in proteins, carbohydrates, polyunsaturated fatty acids, sterols and some more vital elements like calcium, iron, zinc, magnesium, manganese and selenium. It is a natural source of vitamin $\mathrm{B}_{12}$, vitamin $\mathrm{E}$, ascorbic acid, tocopherols and whole spectrum of natural mixed carotene and xanthophyll phytopigments 9 . In the present investigation lead induced histological changes in the liver and kidney tissue of Albino Wister rat and ameliorative effect of Spirulina on the lead toxicity.

\section{MATERIALS AND METHODS}

\section{Animal selection and maintenance}

Adult male albino Wister rats (170-200g) maintained in the University animal house. These were maintained on commercial pellet feed, water and libitum. The ethical committee of Raja Muthaiya Medical College, Annamalai University approved. Before experimentation the animals were housed in PVC cages, which were closed by metal grid in the departmental animal room for the acclimation. The animals were maintained under standard laboratory conditions. They were fed standard diet pellets and water was provided ad libitum.

\section{Toxicity studies}

The heavy metal lead acetated is used as sublethal dose $\left(\mathrm{LD}_{50}\right.$ value is $1.896 \mathrm{mg}$ of lead $/ \mathrm{kg}$ by body weight of the animal for 7 days).

\section{Spirulina powder}

spirulina in the form of powder was obtained from spirulina farm auroville, puducherry.

\section{Drug administration}

The rats were treated with lead acetate and Spirulina in the following way:

1. Lead acetate was weighed accurately and dissolved in distilled water.

2. The Spirulina weighed and dissolved in distilled water.

3. Lead acetate and Spirulina were administered orally into the mouth cavity of the experimental rat with the help of syringe whose tip ended with infant feeding tube.

\section{Experimental design}

After acclimation the rat were divided into four groups. Each group consisted of 5 animals.

Group I: Control

Group II: Oral administration of lead acetate $1.896 \mathrm{mg} / \mathrm{kg}$ body wt for7 days.

Group III: Co-administration of lead acetate $1.896 \mathrm{mg} / \mathrm{kg}$ body wt and Spirulina $2 \mathrm{mg} /$ body wt. orally for 7 days. 
Group IV: Spirulina $2 \mathrm{mg} / \mathrm{kg}$ body wt for 7 days.

At the end of the experiment, all the groups were sacrificed liver and kidney tissue of each animal was dissected for histological studies.

\section{Histological studies}

To examine the extent of cellular damage caused by lead acetate, the liver and kidney of the control and treated tissues were fixed in Bouin's fluid. After 24 hours, the standard histological technique was followed by the method of Gurr ${ }^{10}$.

Liver Tissues

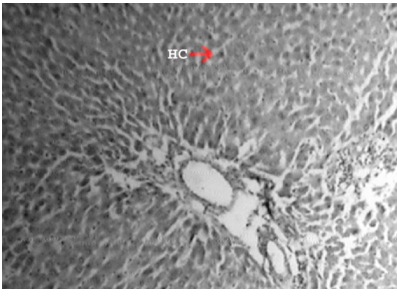

Figure 1: Liver group1

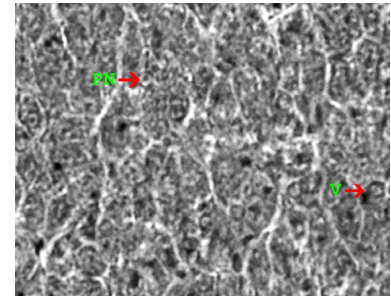

Figure 2: Liver group 2

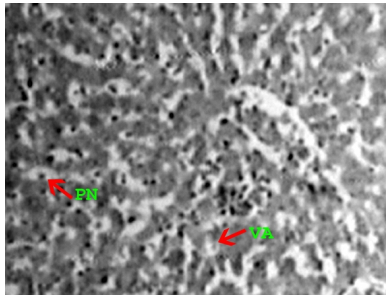

Figure 3: Liver group 3

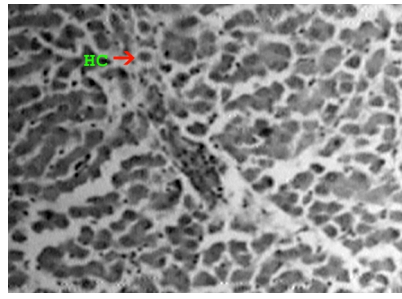

Figure 4: Liver group 4

Figure 1 shows control liver slid, No: 2 shows lead acetate treated (group2), No: 3 shows recover (group 3) lead acetate and Spirulina treated liver, No: 4 shows Spirulina alone treated (group 4) Hepatocyte. HC- Hepatic cells, PN - Pycnotic nucleus, N- Nucleus, V - Vacuolation S - Sinusoids, VA - Vacuoles .

Kidney Tissues

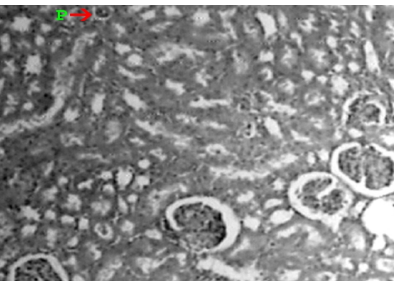

Figure 5: Kidney (group 1)

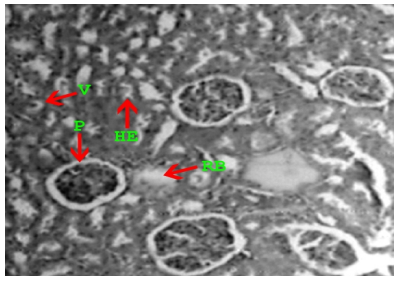

Figure 6: Kidney (group 2)

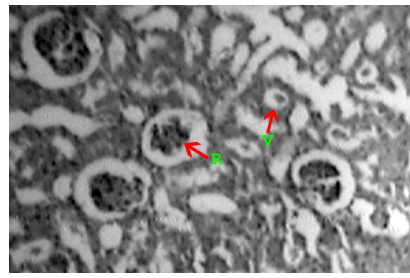

Figure 7: Kidney (group 3)

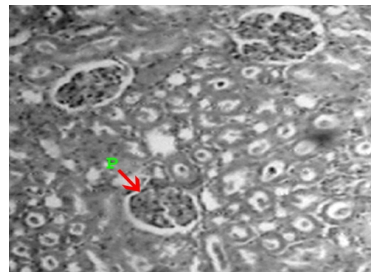

Figure 8: Kidney (group 4)

Figure 1 the control kidney cells (group1), No:2 shows lead acetate teated (group 2) kidney tissues, No:3 shows lead acetate and Spirulina treated (group3) kidney tissue, No:4 shows Spirulina alone treated (group 4) kidney tissues. D - Distal convoluted tubule, P - Proximal convoluted tubule, E- Epithelial BC - Bowman's capsule, HE - Hemopoitic tissues, R- Renal tubule. RB - Ruptured cell boundary, V - Vacuolation

\section{RESULT AND DISCUSSION}

The liver of rat exposed to sublethal concentration of lead acetate shows (Figure 2) drastic changes in the cellular architecture compared to the untreated control (Figure 1). The outer membrane of the liver is ruptured at many points. Variations in the space of hepatocytes are evident in different region of the liver. The blood vessels are destroyed leaving large spaces (vacuoles) with damaged red blood cells (Figure 2). Deterioration of cellular architecture with marked necrosis is also observed. The hepatocytes are found usually in groups with conspicuous spaces between them. Hepatocytes are posses a markedly thickened nuclear and cytoplasmic membrane. This is obliterated at some places. The hepatic ducts have become larger in size. Inter hepatic spaces have been dilated and orientation of nuclei is promiscuous. Nuclear pycnosis, cytoplasmic lysis and karyolysis are observed in different regions. (Figure 2) The degenerated paranchymal cells showed abnormal enlargement and these cells are called hypertropic sized cells, which have increased the volume of the liver. In group III lead acetate along with Spirulina administered rat shows slight cytoplasmic vacuolization, lateralization and condensation of the nuclei were also observed (Figure 3 ). The group IV Spirulina alone administered rat showed the histological pattern to near normalcy (Figure 4). In the present study, lead hepatotoxicity manifests itself in disorganization of the hepatic cords, cytoplasmic vacuolization and invading of infiltrative inflammatory cells ${ }^{11}{ }^{12}$. Since chronic lead toxicity affect on a range of cellular enzymes particularly those involved in energy production and associated with massive dilated mitochondria leading to hydropic degeneration appear as cytoplasmic vacuolization ${ }^{13}$. However, mild and to a lesser extent, moderate degrees of hydropic degeneration and mild portal cellular infiltration were seen in $50-60 \%$ of rats exposed to $\mathrm{Pb}+$ Spirulina. The histological examination of the liver tissue of the animals treated with $\mathrm{Pb}$ revealed severe histopathological changes typical to those reported in the literature. Similar observations were reported by ${ }^{14,-17}$. When Spirulina was given to lead treated rats, the liver had essentially normal appearance in histopathological examination. Spirulina exhibit some protective effects against $\mathrm{Pb}$ intoxication. Albino rat administered to lead acetate has produced some conspicuous histopathological changes in the kidney. The distal and collecting convoluted tubules of the kidney undergo degeneration and have a large lumen due to hypertrophy (Figure 5). The cells of the kidney are destroyed. Vacuolization, shrinkage and breakage of tissue, degeneration of tubular epithelium and swollen nuclei are seen in the kidney (Figure 5). In the some areas, the cells boundaries are disrupted and hence the cells become indistinct. There is an aggregation of blood cells in some areas (Figure 6). Lead administered along with Spirulina exhibited higher protective effects against lead when compared to lead administered rats (Figure 5) while Spirulina alone administered rats (Figure 7) showed histological pattern to near normalcy. In group III, lead acetate along with Spirulina administered rat shows recovered from the toxic effect of lead (group II) epithelial cells of the renal tubules with the consequent 
reduction in tubular lumens (Figure 6). The group IV administered rats' histological pattern to near normal (Figure 8).In the kidneys, lead intoxication causes, among other reactions, intestinal fibrosis, as well as both hyperplasia and gradual atrophy of tubules and glomeruli ${ }^{18}$. It is well known that chronic lead exposure also results in glomerular and tubulointerstitial changes that lead to glycosuria, proteinuria and chronic renal failure and hypertension ${ }^{19,20}$. Another histological indication of $\mathrm{Pb}$ toxicity in the rat kidney shows the karyomegaly of tubular cells ${ }^{21}$. Tubular, intestinal and glomerular damage these findings were supported by the findings of ${ }^{22,23}$ Inclusion bodies rapidly disappear with chelation therapy ${ }^{24}$. This may explain the improvement of histological findings in the kidneys, especially number of cells exhibiting. Karyomegaly and intranuclear inclusions $\mathrm{Pb}$ intoxicated rats' supplemented with Spirulina. Several studies have focused on physiological properties of some valuable antiviral or antioxidant compounds in blue green alga Spirulina ${ }^{25,26,27 .}$ Spirulina species exhibit various biological activities such as antitumour ${ }^{28,29}$ Antimicrobial ${ }^{30}$ metalloprotective ${ }^{31}$.

\section{CONCLUSION}

In the present investigation leads induce cell damages causes' histological alteration in the cells. Supplementary spirulina enhance the cell repairing mechanism and chelating the toxic lead substance to the animal body. This chelating capability may happen due to nutritive elements and vitamins present in the spirulina.

\section{REFERENCES}

1. Larison JR Likens E Fitzpatrick JW and. Crock JG Cadmium toxicity among wildlife in the Colorado Rocky Mountains. Nature2000: 406: 181-183. http://dx.doi.org/10.1038/35018068 PMid:10910356

2. More TG Rajput RA and Bande NN. Impact heavy metals on DNA content in the whole body of fresh water bivalue, Lamelleiden marginalis. Environ. Poll. Sci. Res2003: 22: 605-616.

3. Cheng S. Heavy metal pollution in China: origin, pattern and control. Environ. Sci. Poll. Res2003: 10: 192-198. http://dx.doi.org/10.1065/espr2002.11.141.1

4. Ashry KM El-Sayed YS Khamiss RM and El-Ashmawy IM. Oxidative stress and immunotoxic effects of lead and their amelioration with myrrh (Commiphoramolmol) emulsion. Food Chem. Toxicol2010: 48: 236-41. http://dx.doi.org/10.1016/j.fct.2009.10.006 PMid:19818824

5. Kostial K Blanus M Piasek M Resteck-Samarzija N Jones M and Singh P. Combined chelation therapy in reducing tissue lead concentrations in suckling rats. J. Appl. Toxicol 1999: 19: 143-147. http://dx.doi.org/10.1002/(SICI)10991263(199905/06)19:3<143::AID-JAT562>3.0.CO;2-G

6. Patra RC Swarup D and Dwivedi SK. Antioxidant effects of $\alpha$-tocopherol, ascorbic acid and L-methionine on lead induced oxidative stress to the liver, kidney and brain in rats. Toxicology 2001:162: 81-88. http://dx.doi.org/ 10.1016/S0300-483X(01)00345-6

7. Shalan MG Mostafa MS Hassouna MM El-Nabi SE and El-Refaie A. Amelioration of lead toxicity on rat liver with vitamin $\mathrm{C}$ and silymarin supplements. Toxicology2005: 206:1-15. http://dx.doi.org/ 10.1016/i.tox.2004.07.006 PMid:15590105

8. Bernet D Schmidt H Meie W Burkhardt-Holm P Wahli T. Histopathology in fish: proposal for a protocol to assess aquatic pollution. J. Fish Dis 1999:22: 25 34. http://dx.doi.org/10.1046/j.1365-2761.1999.00134.x

9. Chamorro G Salazar M and Favila L. Pharmacology and toxicology of Spirulina alga. Rev. Invert. Clin1996: 48: 389-399. PMid:9005517

10. Gurr, E., 1959. Methods for analytical histology and histochemistry, Leonard Hill (Book), Ltd., London.

11. Pereira R Pereira ML Ribeiro R and F. Goncalves. Wildlife animals as sentinels to human health due to environmental exposure to heavy metals. In: Abstract book. In: Proceedings of the 11th annual meeting, SETAC Europe 2001: 6-10 May: Soc. Environ. Toxicol. Chem., Madrid, p.108.

12. El-Sokkary GH Abdel-Rahman GH and Kamel ES Melatonin protects against lead-induced hepatic and renal toxicity in male rats. Toxicology2005:312: 2533. http://dx.doi.org/10.1016/j.tox.2005.05.003 PMid:15964675
13. Buchheim K Stoltenburg-Didinger G Lilienthal H and Winneke G. Myopathy: a possible effect of chronic low level lead exposure. NeurotoxicologY1996:19: 539-45.

14. Fracasso ME Perbellini L Solda S Talamini G and Franceschetti P. Lead induced DNA strand breaks in lymphocytes of exposed workers: role of reactive oxygen species and protein kinase C. Mutat. Res2002: 515: 159-169. http://dx.doi.org/10.1016/S1383-5718(02)00012-8

15. Valverde M Fortoul TI Diaz-Barriga F Mejia J and del Castillo ER. Genotoxicity induced in Cd-1 mice by inhaled lead: differential organ response. Mutagenesis2002: $\quad$ 17: $\quad$ 55-61. $\quad$ http://dx.doi.org/10.1093/mutage/17.1.55 PMid: 11752234

16. Danadevi K Rozati R Saleha-Banu B Hanumanth-Rao P and Grover P DNA damage in workers exposed to lead using comet assay. Toxicology 2003:187: 183-193. http://dx.doi.org/10.1016/S0300-483X(03)00054-4

17. Hengstler JG Bolm-Audroff U Faldum A JanssenK Reifenrath M Gotte W Jung D Mayer-Popken O Fuchs J et al.Occupational exposure to heavy metals: DNA damage induction and DNA repair inhibition prove co-exposures to cadmium, cobalt and lead as more dangerous than hitherto expected. Carcinogenesis2003: 24: 63-73. http://dx.doi.org/10.1093/carcin/24.1.63 PMid: 12538350

18. Houston, DK and Johnson MA. Does vitamin C intake protect against lead toxicity? Nutr. Rev2000:58: 73-75. http://dx.doi.org/10.1111/j.17534887.2000.tb01842.x PMid:10812921

19. Nolan CV and Shaikh ZA Lead nephrotoxicity and associated disorders: biochemical mechanism. Toxicol 1992: 73: 127-146. http://dx.doi.org/10.1016/0300-483X(92)90097-X

20. Kim R Rotnitzky A Sparrow D Weiss ST Wager C and Hu H. A longitudinal study of low-level lead exposure and impairment of renal function. JAMA 1996: 275: 1177-1181. http://dx.doi.org/10.1001/jama.1996.03530390043032 PMid:8609685

21. Loghman-Adham M. Renal effects of environmental and occupational lead exposure. Environ. Hlth. Perspect1997:105: 928-938. http://dx.doi.org/ 10.1289/ehp.97105928 PMid:9300927 PMCid:1470371

22. Payne BJ and Saunders LZ. Heavy metal nephropathy of rodents. Vet. Pathol1978: 15: 51-87. PMid:104422

23. Romeo M Bennani N Gnassia-Borelli M Lafaurie M and Girard JP. Cadmium and copper display different; responses towards oxidative stress in the kidney of the sea bass Dicentrarchus labrax. Aquat. Toxicol2000: 48: 185-194. http://dx.doi.org/10.1016/S0166-445X(99)00039-9

24. Patra RC Swarup Dand Dwivedi SK. Antioxidant effects of $\alpha$-tocopherol, ascorbic acid and L-methionine on lead induced oxidative stress to the liver, kidney and brain in rats. Toxicology2001: 162: 81-88. http: //dx.doi.org/10.1016/S0300-483X(01)00345-6

25. Alden CL and Khan KNM In 2nd Ed. Haschek, W.M., editor, Handbook of Toxicologic Pathology2002, vol. 2. San Diego, Academic Press, California, pp. 225-336.

26. Ozdemir G Karabay NU Dalay CM and Pazarbasi B. Antibacterial activity of volatile component and various extracts of Spirulina platensis. Phytother Res2004: 18: 754-757. http://dx.doi.org/10.1002/ptr.1541 PMid:15478198

27. Khan M Shobh CJ Rao UM Sundaram CM Singh S Mohan JL Kuppusamy P and Kutala KV Protective effect of Spirulina against doxorubicin-induced cardiotoxicity. Phytother. Res2005:19: 1030-1037. http://dx.doi.org 110.1002/ptr.1783 PMid:16372368

28. Khan M Shobha CJ Mohan JL Rao UM Prayag AN and Kutala KV Spirulina attenuates cyclosporine-induced nephrotoxicity in rats. J Appl Toxicol 2006: 26 : 444-451. http://dx.doi.org/10.1002/jat.1159 PMid:16858688

29. Mittal A and Suresh Kumar PV. Modulatory potential of Spirulina fusiformis on carcinogen metabolizing enzymes in Swiss albino mice. Phytother. Res1999 :13: 111-114. $\quad$ http://dx.doi.org/10.1002/(SICI)1099-1573(199903) 13:2<111::AID-PTR386>3.3.CO;2-U

30. Hayashi $\mathrm{K}$ and Hayashi T. A natural sulphated polysaccharide, calcium spirulin isolated from Spirulina plantensis: in vitro and ex vivo evaluation of anti herpes simplex virus and antihuman immunodeficiency virus activities. AIDS Res. Hum. Retrovir1996: 12: 1463-1471. http://dx.doi.org/10.1089/aid.1996.12.1463 PMid:8893054

31. Sharma MK and Sharma A. Spirulina fusiformis provides production against mercury chloride induced oxidative stress in Swiss albino mice. Food Chem Toxicol 2007: 45: 2412-2419. http://dx.doi.org/10.1016/j.fct.2007.06.023 $\underline{\text { PMid: } 17706852}$

Cite this article as:

K.Hemalatha, K.Pugazhendy, M.Meenambal, C.Jayanthi. Sequestration property of Spirulina against lead induced histological changes in male albino wister rat Rattus norvegicus. Int. Res. J. Pharm. 2013; 4(3):153-155 